\title{
Cadaver nephrectomy: an operation on the donor's family
}

\author{
J B MORTON, D R A LEONARD
}

British Medical fournal, 1979, 1, 239-241

\section{Summary and conclusions}

Thirty-two relatives of cadaver kidney donors were interviewed six months or longer after the donor's death. Most had positive attitudes to kidney transplantation that had been strengthened by experience, especially when they knew that they were fulfilling the donor's wishes. Twenty-three of the relatives had gained some solace from knowing that others might benefit from their misfortune, but three claimed adverse effects. In identifying the factors that influenced them to grant permission or hesitate, relatives revealed defects in the way their permission had been sought. Twelve did not clearly understand the donor's hopeless prognosis until then, and seven reacted adversely to the interviewers, finding them blunt and callous. Nevertheless, most were pleased that they had been asked.

Doctors who care for unconscious, dying patients should try to give relatives explicit information on the patient's condition, whether or not the patient is a potential kidney donor, and permission for organ recovery should not be sought until they understand that death is inevitable.

\section{Introduction}

Potential cadaver kidney donors are usually young patients with a catastrophic head injury or subarachnoid haemorrhage. They

\footnotetext{
University Department of Surgery, Christchurch Clinical School of Medicine, Christchurch Hospital, Christchurch, New Zealand J B MORTON, FRACS, senior lecturer

D R A LEONARD, PHD, MB, resident medical officer
}

may not be notified to a transplantation service if their doctors assume that interviews for permission to use kidneys and to recover organs after death will add further burdens to the grieving families. Little recorded evidence exists to support or deny this assumption. How do relatives react to the experience ? How far does the manner in which they are told of the prognosis and the possibilities of transplantation influence their attitudes? Which events become fixed in their memories, and what influence does the experience have on their grieving ? Would the problem be avoided if the law were amended to remove the obligation for relatives' consent ? One of us had considered these questions when seeking permission from potential donor's relatives, and the other (not a member of the transplantation service) interviewed families of cadaver kidney donors to try to find the answers.

\section{Donors and relatives}

During four years $\mathbf{4 0}$ potential donors had been notified. Forty-four individuals or groups of relatives had been interviewed for permission to recover kidneys (everyone who might consider themselves next of kin-for example, de-facto and legal wives-had been interviewed). A transplant surgeon usually conducted the interview unless a member of the team caring for the donor wished to do so. Permission had been refused for three of the $\mathbf{4 0}$ potential donors.

\section{FOLLOW-UP SURVEY}

A follow-up survey of relatives' experiences and attitudes was made by interviewing 32 of the 44 individuals or groups of relatives who were still living in the city when the study was conducted. Those interviewed included two families who had refused permission. Relatives were first approached by telephone, then interviewed in their own homes. When appropriate this interview was a family affair. It was conversational and usually lasted two hours (range 30 minutes to four hours). Towards the end of each interview a list was used to check that $\mathbf{4 5}$ questions had been answered. 


\section{Results}

When telephoned all the relatives were willing to be interviewed, many expressing a keen interest, especially in the fate of the transplanted kidneys. Some had unanswered questions and unresolved doubts that they wished to discuss with an informed person.

\section{KNOWLEDGE AND ATTITUDES}

When interviewed about their initial knowledge of kidney transplantation, 31 of the 32 relatives knew that the procedure was performed in Christchurch, 19 considered the procedure to have reasonable results, and $16 \mathrm{knew}$ that donors could be living relatives or cadavers. Table I summarises relatives' attitudes to transplantation before and after experience. None was "strongly opposed" to the procedure. Only three out of $\mathbf{4 4}$ relatives refused, which reflects a positive attitude before experience and suggests that the attitude was strengthened rather than weakened by experience.

TABLE I-Attitudes of 32 relatives to cadaver kidney donation before and after experience

\begin{tabular}{lccccc}
\hline & $\begin{array}{c}\text { Strongly } \\
\text { in } \\
\text { favour }\end{array}$ & $\begin{array}{c}\text { In } \\
\text { favour }\end{array}$ & Neutral & $\begin{array}{c}\text { Not } \\
\text { in } \\
\text { favour }\end{array}$ & $\begin{array}{c}\text { No } \\
\text { considered } \\
\text { attitude }\end{array}$ \\
\hline $\begin{array}{l}\text { Before experience } \\
\text { After experience }\end{array}$ & 2 & 25 & 1 & 1 & 3 \\
\hline
\end{tabular}

\section{UNDERSTANDING PROGNOSIS WHEN PERMISSION SOUGHT}

All but two relatives were surprised when the subject of donation was first raised, and some thought that it was callous to raise the subject at that time. For 12 the surprise was stunning because only then did they realise the gravity of the patient's condition. Many of the others felt despondent: although they knew that death was imminent, all hope was then dashed. Nine of the 12 wished that there had been more time between realisation that death was inevitable and the interview. None of those who were aware of the prognosis would have wanted more time, even though they had usually known for less than an hour or two.

\section{MEMORIES OF THE INTERVIEW}

Twenty-five families remembered the interviewers as impartial and kind. Relatives had hostile reactions to three out of five interviews with junior doctors and four out of 27 interviews with surgeons. The most experienced interviewer provoked antagonism twice in 19 encounters. A salesman considered the approach "salesman-like," and resented it, and another was opposed to transplantation and had refused permission. Four other relatives portrayed the interviewers as blunt, callous, and more concerned with procuring kidneys than with the plight of the patient or family. One wife was muddled and confused by a foreign doctor whose knowledge of the language was inadequate. Of these seven who reacted adversely, only three wished, at follow-up, that they had not been asked for permission.

Some adverse reactions occurred after the interview. The time between granting permission and death was particularly distressing for six relatives. For one it was profoundly so, being an unusually long 20 hours. One mother became depressed after her son's death when her daughter accused her of giving permission for her son to die. Eventually she was consoled by the hospital superintendent, who convinced her that death had been inevitable.

\section{MOTIVATING FACTORS IN GRANTING OR DENYING PERMISSION}

Relatives were motivated to grant permission by a combination of factors (table II). Most wanted to give others a second chance: "I can remember thinking what a godsend to salvage something from an otherwise wasted young body," as one young widow expressed it Another said: "She was always helping others and here was a chance for her to do so in death." Twenty-six relatives thought that the patient would have wished to donate kidneys, and no fewer than 10 were certain because the patient had informed them so before the disaster.
TABLE II-Factors that motivated 30 relatives to grant permission for cadaver kidney donation

Known wish of donor

Desire to help others

Desire for some good to result from donor's death"

Wish to help the doctors

Many had considered whether granting permission would prejudice the patient's care. Initially, some had feared that they might be actively contributing to the death. Kidneys might be removed before all chance of survival had passed. All but one were satisfied by the explanations given in the interview. Many families were averse to having the donor "cut." Indeed, this was the reason given for the two refusals, despite the knowledge that a coroner's postmortem examination was inevitable.

\section{ATTITUDES TO THE CARING TEAM}

The relatives' attitudes to the caring teams seemed closely related to the time that had been spent with them. The nursing staff were complimented without exception. Many relatives wished that the doctors had been able to see them more often and be more explicit, especially about the prognosis. The hospital chaplains had been concerned with five relatives only, but their attention was appreciated by all. Six relatives had asked their family doctors to clarify certain points, but found them hampered by a lack of precise information.

\section{EFFECT OF DONATION ON RELATIVES' GRIEVING}

Of the 30 relatives who granted permission, five thought that their decision had not affected grieving, most (23) considered it beneficial, and the two people who said that they were adversely affected were ambivalent about whether they had made the right decision. One of the people who refused permission was not affected by the decision, but we could not ascertain why the other felt that her grief had been increased.

\section{Discussion}

In this study the relatives of cadaver kidney donors described their motives, fears, and reactions, and some recalled unpleasant experiences that could have been avoided. When permission was sought most recognised the need for organs, probably as a result of support for transplantation by the local press, and the refusal rate was low. After the donor's death many relatives gained some solace in their grieving from knowing that their death may not have been entirely in vain.

The interview for permission came as a shock, which made the request seem callous when the prognosis was not clearly understood. We urge doctors caring for dying, unconscious patients to provide explicit information to the family, whether or not the patient is a potential kidney donor. Permission for organ recovery should not be sought until relatives understand the donor's hopeless condition, and the necessity to discontinue artificial ventilation, whether or not permission is granted, should be explained.

The setting in which cadaver donation occurs may be trying and fragile, and the interview should not be approached lightly. The donor's doctor, who is often in the best position to obtain permission without causing distress, usually escapes the task, possibly to avoid suspicion of having a vested interest. Although the numbers in this study were small, experienced interviewers obtained permission, with less harrowing encounters, than junior staff. Families were informed to their satisfaction and enabled to reach a decision without pressure. Kindred souls, disturbed by uncertainty while donors lay brain dead with beating hearts, echoed Macbeth's plea, "If it were done, when 'tis done, then 'twere well it were done quickly."

Fulfilling the donor's wishes was comforting to relatives. To 
encourage people to decide about their wishes before they become potential donors, a television documentary, including a simulated interview for permission, has been shown. Since many gained solace from donation, of which they would be deprived if the law were amended, consent should remain obligatory. The evidence in this community does not suggest that changing the law would increase the supply of organs.

Finally, the follow-up interview was well received. We intend to continue this to provide information and to acknowledge that cadaver transplantation depends on the good will of the community. Thus the term "harvesting" should be expunged from reports on transplantation and reserved for agricultural pursuits. "Recovery" or "retrieval" are more conducive to the spirit of humane care.

(Accepted 26 October 1978)

\section{MATERIA NON MEDICA}

\section{Beware of the knitting machine}

Do think twice before buying your wife a knitting machine. I should have suspected that something was afoot when, after a particularly good dinner, with a bottle of Marks and Sparks best, my wife suggested that it might be a good idea if she had such a machine.

"Think how much it would save," she said, "the children are always needing new sweaters and it would be much cheaper if I could make them myself. I could make Christmas presents too." I am always interested in anything that means spending less money and was easily convinced that we couldn't possibly do without this modern miracle. I even entertained the thought of a few things for myself, being very low in the pecking order for anything hand knitted.

So catalogues were consulted, magazines read, Which? reports analysed, and demonstrations arranged. The final choice was made and the monster purchased.

"Where will you keep it ?" I asked-"Oh, that's all decided," she replied. It's going in the spare room. I must have it somewhere where I can leave it all rigged up and ready for use." So the spare room has now become the knitting-machine room-piles of wool here, knitting patterns there, oil cans and the other paraphernalia of maintenance somewhere else.

Parcels of wool arrive with monotonous regularity. Unfortunately our postman comes at 6 am and, not wishing to leave anything on the doorstep, rings the bell. Guess who has to get up and answer it.

The children now have sweaters with designs going clockwise, anticlockwise, up and down, and back to front. We have Leeds United jumpers, scarves, and bobble hats. I have pullovers with polo necks, turtle necks, vee necks, long sleeves, short sleeves, no sleeves. Even the grandparents' "Just what I wanted" seems to be said with a little less enthusiasm with each passing Christmas and birthday.

My wife disappears to the "knitting-machine room" every evening and all we hear is the swish-swish of the carriage as it goes back and forth. I expect I shall find her one day, like a latterday Sleeping Beauty, fast asleep having pricked her finger with one of the needles.

To gain more experience she's going to evening classes and comes back each week with "homework." There's even talk of some sort of postgraduate weekend of knitmanship in some distant city. But the children aren't too keen on this. Half a dozen new garments will not compensate for a weekend of my cooking.

But never mind, think of all the money we are saving.-E R G ANDERTON (general practitioner, Lancaster).

\section{William Hyde Wollaston}

William Hyde Wollaston died 150 years ago. A son and brother of fellows of the Royal Society, he was himself its secretary for 12 years; he became a doctor in 1788 and a censor of the Royal College of Physicians in 1798; was one time fellow of Caius College and Greek and Hebrew lecturer; and was a physician in East Anglia before moving to London. In 1800 he retired from medical practice, probably because of "oversensitivity and overanxiety for his patients" (Dictionary of National Biography). Suddenly he was poor, but in his back garden laboratory near Fitzroy Square he learnt how to make platinum malleable. He kept his method secret and reaped $£ 30000$. While purifying platinum he discovered two new metals, palladium and rhodium.

He and Sir Humphry Davy and Dr Thomas Young ranked as the most eminent representatives of English science of their age, "but he was wanting in the courage of Young and the enthusiasm of Davy" (Munk's Roll of Fellows of the RCP) - that is, he did not publish his results unless he was sure of them.

$\mathrm{He}$ analysed renal stones, showing that calcium phosphate and other salts contributed to their composition; he discovered cystine, which he called cystic oxide-"bladder oxide." He devised a goniometer (for measuring the angles of crystals), which used light beams instead of mechanical levers so that it was a much more precise instrument and could be used for small crystals. He showed that explosions did not travel along small tubes, and Davy put the observation to the proof in his miners' lamp. Wollaston rejected the decimal system but proposed that our different gallons should be replaced by one, the imperial gallon weighing $10 \mathrm{lb}$. ("A pint of water weighs a pound and a quarter.") His 54 scientific papers covered topics in "pathology, physiology, chemistry, optics, mineralogy, crystallography, astronomy, electricity, mechanics, and botany."

He deduced the hemidecussation of the optic nerves and himself suffered from attacks of blindness. In 1828 his left pupil became unresponsive. He described his symptoms anonymously to a friend who diagnosed cerebral tumour. Wollaston promptly set to work dictating notes and directing his last experiments from his bed. After five months he was speechless, dying. A friend said in his hearing that he was no longer conscious. Wollaston gestured for pencil and paper, wrote down a column of figures, totted them up and handed his friend the sum. It was correct.-PHILIP EVANS (paediatrician, London).

\section{Bookbinding}

Many years ago I acquired a rich assortment of bookbinding tools and materials. They had belonged to an Indian Medical Service doctor who had taken a course in bookbinding on early retirement and had practised this craft in a small Suffolk village until he died in his 80 s. I used to gaze at this collection with perplexity, wondering when I should learn to use the tools with such strange names-trindles, laying presses, band-nippers, and burnishers. I felt like a child who had inherited a euphonium and was unable to play it. Eventually I enrolled in an evening class and sat among day-release apprentices from a local printing firm. But here we used electric guillotines, block-lettering, and other sophisticated equipment, and my homely tools remained strangers to me. Recently a craft teacher has come to Norfolk, and now my bookbinding tools no longer lie neglected and unused. We have transformed pamphlets into elegant little books, made cased books and library style volumes, and now we have begun true bookbinding - that is, sewing on cords and binding in leathera technique that has changed very little since mediaeval times. Soon we shall begin gold lettering and tooling, and then I hope to see my bound volumes glittering like stars in their bookish firmament.

The earliest true bindings were made by the Coptic church in the seventh and eighth centuries. In this country we have St Cuthbert's Gospel, bound in red goatskin, dating from the seventh century and now in the library at Stonyhurst College. English bookbinding reached its finest flowering in the later seventeenth century, as a visit to Pepys's library at Magdalene College, Cambridge, will convince any bibliophile. Charles II employed the renowned bookbinder Samuel Mearne, and it was he who popularised the peculiarly English "cottagestyle" binding. The craft suffered an eclipse in the early nineteenth century, when binding cloth was introduced, but in later Victorian times William Morris and Cobden Sanderson revitalised it and this interest has survived till the present day. A few professional bookbinders still produce high-quality work, but their books are excessively expensive, especially hand-bound leather volumes. The craft will no doubt be continued by firms specialising in the conservation of old books, and by enthusiastic amateurs.

Bookbinding demands accuracy, patience, and a knowledge of the materials used: it is a rewarding hobby which can be pursued when it is too wet for gardening or too frosty to play golf. Wives should encourage it.-PETER BEATTIE (ophthalmic surgeon, Norwich). 